\title{
The Natural Dyes as Applied to Wool.
}

BY H. T. VULTÉ AND D. W. WARD.

The work deseribed in this brief memoir was undertaken some five years ago, and from causes unseen at that time the publication has been delayed until the present.

As originally designed, the work was merely the preparation of a large series of samples of wool dyed with various natural dyestuffs and common mordants as an exhibit of this branch of the dyer's art now rapidly going out of use.

During the prosecution of the work it was seen that a valuable comparative method of testing these dyes might be evolved from the facts as recorded in the results of these tests.

The samples were prepared from pieces of woollen flannel of known purity weighing ten grams each, washed, mordanted in the proper baths, washed arain, and dyed in a bath of the dye carefully prepared, the conditions differing with the various dyestuffs.

225 samples were made, with 5 mordants, the list including the following dyestuffs :-

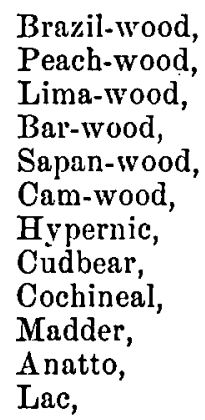

Catechu, Quercitron, Barberry root, Sumach, Saffron, Weld, Fustic, Turmeric, Persian berries, Logwood, Tannin.

The method proposed for testing or valuation of a dyestuff is briefly as follows:-

For instance, logwood: Ten grams of flannel are mordanted with alumina sulphate for one hour at $212^{\circ} \mathrm{F}$., then cooled, washed, and divided in two equal parts; one part is dyed in a 10 per cent. bath of standard chips for one hour at $212^{\circ} \mathrm{F}$. and the other part in a 10 per cent. bath of the logwood to be tested under the same conditions. The two pieces are finally removed from their respective baths, dried, and compared as to shade. It is well to have a few samples of $1,2 \frac{1}{2}$, and 5 per cent. standard dye for comparison. With a little practice the shade may easily be matched within 1 per cent. It is best always to choose the brilliant sbades for comparison. I have had no difficulty in keeping standard samples, provided they are protected from strong sunlight.

The following formula used in these tests will be found inter- 
esting. The figures are always based on the 10 gram swatch of wool :-

\section{BRAZIL-WOOD.}

No. $1(10106,10107 \mathrm{R}, 10108 \mathrm{R})$.

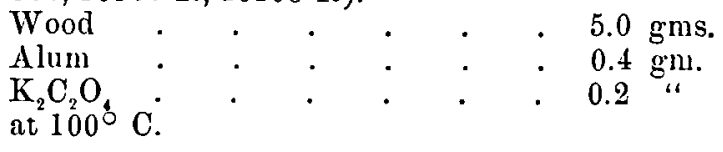

Bluish-red.-No. 10106.

Boil 1-1 $\frac{1}{2}$ hours, wash, dye in separate bath $\frac{1}{2}-1$ bour at $80^{\circ}-100^{\circ}$ C. $5.0 \mathrm{gms}$. dye-wood; add to dye-bath $0.6-1.2 \mathrm{gms}$. $\mathrm{CaCO}_{3}$, also solution of glue. (See Lima-wood.)

Peach-wood same.

No. 2 (10112) $\mathrm{K}_{2} \mathrm{Cr}_{2} \mathrm{O}$.

$$
\mathrm{K}_{2} \mathrm{Cr}_{2} \mathrm{O}_{7} \text {. . . . . } 0.3 \mathrm{gm} \text {. }
$$

Boil for $1 \frac{1}{2}$ hours; take out, wash, and boil in the dye-bath for 1 hour. Wood

No. 1 (10110) FeSO.

Boil in a bath of the

Wood

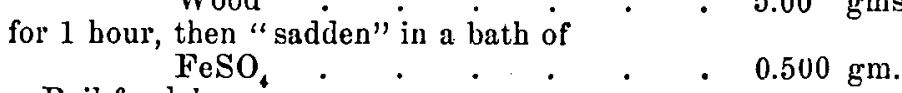

Boil for $\frac{1}{2}$ hour.

No. 2 (10111) CuSO.

Same as above, but use $\mathrm{CuSO}_{4}$ instead of Iron.

$\mathrm{CuSO}_{4} \cdot . \quad . \quad . \quad .0 .8000 \mathrm{gm}$.

No. 3 (10109) $\mathrm{SuCl}_{2}$.

Boil in the mordant for 1 hour.

$$
\begin{array}{llllllll}
\mathrm{SnCl}_{2} & \cdot & \cdot & \cdot & \cdot & \cdot & \cdot & 0.100 \mathrm{gm} . \\
\text { Tartar } & \cdot & \cdot & \cdot & \cdot & \cdot & \cdot & 1.600 \mathrm{gms} .
\end{array}
$$

Take out, wash, and dye

Boil for 1 hour.

$$
\text { Wood . . . . } \quad 5.00 \mathrm{gms} \text {. }
$$

Stannic tin.

\section{Hypernic.}

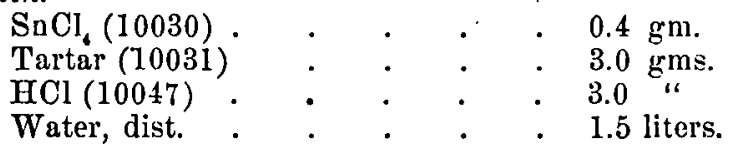


Boil for 11 hours; take out, wash, and dye in a bath of Wood . . . . . . $7.0 \mathrm{gms}$. Water, dist. . . . . . . 1.5 litres.

Boil for 1 hour with frequent agitation; take out and wash. Red-wood same way, but use $8.0 \mathrm{gms}$. of wood.

No. 10162.

Boil in a bath of

Wood . . . . . $6.000 \mathrm{gms}$. for 1 hour, then wash and sadden in the alumina bath

Boil for 1 hour.

$\mathrm{Al}_{2}\left(\mathrm{SO}_{4}\right)_{3} \cdot$. $. \quad . \quad 1.000 \mathrm{gms}$.

No. 10161.

Boil in $\mathrm{CuSO}_{4}$ for $1 \frac{1}{2}$ hours

$\mathrm{CuSO}$, . . . . . $0.800 \mathrm{gm}$.

Take out, wash, and dye in a separate bath Wood

6.00 gms.

Boil for $1 \frac{1}{2}$ hours.

\section{Peach-WoOd.}

No. 1 (10150, 10151) $\mathrm{K}_{2} \mathrm{Cr}_{2} \mathrm{O}_{7}$.

$\mathrm{K}_{2} \mathrm{Cr}_{2} \mathrm{O}_{7} \cdot{ }^{2} \cdot . \cdot 0.300 \mathrm{gm}$.

Boil for $1 \frac{1}{2}$ hours; take out, wash, and dye in a separate bath Wood . . . . . . 4.000 gms.

No. 2. Same as No. 1, using

Wood . . . . . 6.000 gms.

No. 1. $\mathrm{Al}_{2}\left(\mathrm{SO}_{4}\right)_{3}$.

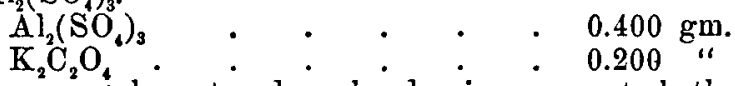

Boil $1 \frac{1}{2}$ hours; take out and wash; dye in a separate bath Wood

No. 2. Same as No. 1, using

Wood . . . . 6.000 gms.

No. 10155, 10156, 10157, Al, Sn, and Tartar.

(1) 40 per cent. of wood.

$$
\begin{aligned}
& \mathrm{Al}_{2}\left(\mathrm{SO}_{4}\right)_{3} \quad \cdot \quad \cdot \quad . \quad \cdot 0.600 \mathrm{gm} \text {. }
\end{aligned}
$$

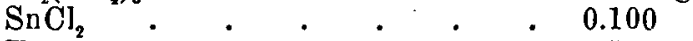

$$
\begin{aligned}
& \text { Tartar : } \cdot{ }^{\circ} \cdot 0.500 \text { “ }
\end{aligned}
$$

(2) 60

(3) 20

No. 3 (10155) Al:.

Boil in a bath of

Wood

Chalk

$6.000 \mathrm{gms}$.

$0.600 \mathrm{gm}$. 
for one hour ; take out, wash, and sadden in a bath of

Boil for $\frac{1}{2}-\frac{3}{4}$ hour.

$$
\begin{array}{llllllll}
\mathrm{Al}_{2}\left(\mathrm{SO}_{4}\right)_{3} & \cdot & \cdot & \cdot & \cdot & . & 0.600 & \mathrm{gm} . \\
\text { Tartar } & . & . & . & . & . & 0.500
\end{array}
$$

No. 4 (10154) $\mathrm{SnCl}_{2}$.

Boil in a bath of

$$
\begin{aligned}
& \mathrm{SnCl}_{2} \text {. . . . . } \quad .0 .200 \mathrm{gm} \text {. } \\
& \text { Tartar . . . . . . } 0.500 \text { " } \\
& (\mathrm{HCl}) \cdot .+. \text {. . . . }
\end{aligned}
$$

for $1 \frac{1}{2}$ hours; take out, wash, and dye in a bath of

Wood

Boil for 1 hour. Uंse distilled water.

6.00 gus.

No. 1 (10153) $\mathrm{FeSO}_{4}$.

Boil with

$$
\begin{aligned}
& \text { Wood . . . . . . } 6.00 \mathrm{gms} \text {. } \\
& \mathrm{CaCO}_{3} .+. \quad .0 .800 \mathrm{gm} \text {. }
\end{aligned}
$$

for 1 hour; take out, wash, and sadden with

Boil for $\frac{1}{2}$ hour.

$$
\begin{array}{llllllll}
\mathrm{FeSO}_{4} & \cdot & \cdot & \cdot & \cdot & \cdot & \cdot & 0.500 \mathrm{gn} . \\
\text { Tartar } & \cdot & \cdot & \cdot & \cdot & : & \cdot & 0.800
\end{array}
$$

No. 2. $\mathrm{CuSO}_{4}$.

Boil with

Chalk . . . . . $\quad . \quad 0.800 \mathrm{gm}$. Wood • • • • . $\quad 6.000 \mathrm{gms}$. take out, wash, and sadden in a bath of $\mathrm{CuSO}_{4} \cdot . \cdot{ }^{\circ} .0 .800 \mathrm{gm}$.

Boil for $\frac{1}{2}$ hour.

\section{REDWOOD.}

No. 1.

$$
\mathrm{K}_{2} \mathrm{Cr}_{2} \mathrm{O}_{4} \cdot .+. \quad \cdot 0.200 \mathrm{gm} \text {. }
$$

Boil for $1 \frac{1}{2}$ hours, and dye in a separate bath Wood - 4.0-8.0 gms.

No. 2 (10115) Alumina.

Boil the wool first with $2.0-8.0$ gms. of the wood for 1 to $1 \frac{1}{2}$ hours; then boil in a separate bath of
$\mathrm{Al}_{2}\left(\mathrm{SO}_{4}\right)_{3}$
$0.100 \mathrm{gm}$.

\section{BAR-WOOD.}

No. 1 (10113) $\mathrm{SnCl}_{2}$.

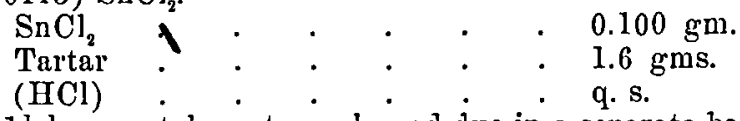

Boil for $1 \frac{1}{2}$ hours; take out, wash, and dye in a separate bath Wood

Boil for 1 hour. Uंse distilled water. 
No. 2 (10114) $\mathrm{CuSO}_{4}$.

Boil with wood for 1 hour

Wood . . . . . 8.00 gms.

then sadden in a bath of $\mathrm{CuSO}_{4}$. . . . . $0.800 \mathrm{gm}$.

Boil for $\frac{1}{2}$ hour.

No. 3. Same as No 2, but sadden with $\mathrm{FeSO}_{4} \cdot$. . . . $0.500 \mathrm{gm}$.

No. 4.

$$
\begin{aligned}
& \mathrm{SnCl}_{4} 1.6^{\circ} \cdot \cdot \quad \cdot \quad \cdot \quad \cdot \quad \cdot 0.4-0.6 \\
& \text { Tartar . . . .. . . 4.0-16.00 gms. }
\end{aligned}
$$

Mordant $1 \frac{1}{2}-2$ hours; wash and boil $1-2$ hours. $4.0-8.0 \mathrm{gms}$. wood.

Bar-wood = Crimson.

Cam-wood = Purplish-red.

Sanders-wood $=$ Yellow-red.

Stuffing and Saddening.-Boil with
Wood
$8.0 \mathrm{gms}$.
Water, dist.
1.5 liters

for 1 hour ; take out, wash, and sadden in a bath of
$\mathrm{SnCl}_{2}$
$0.4 \mathrm{gm}$.
$\mathrm{HCl} \quad . \quad$. $\quad$. $\quad . \quad .2 .0 \mathrm{cc}$.
Water, dist. . . . . . 1.5 liters.

Boil $\frac{3}{4}$ hour; take out and wash thoroughly.

No. 1. $\mathrm{K}_{2} \mathrm{Cr}_{2} \mathrm{O}_{7}$.

Nic-wood.

Boil with

$\mathrm{K}_{2} \mathrm{Cr}_{2} \mathrm{O}_{7} \cdot \cdot \cdot \cdot \cdot 0.300 \mathrm{gm}$.

for $1 \frac{1}{2}$ hours; take out, wash, and dye in a bath of

Wood . . . . $5.000 \mathrm{gms}$.

Boil for 1 hour.

No. 2. $\mathrm{FeSO}_{4}$.

Boil with the wood first

Wood . . . . $5.000 \mathrm{gms}$.

for 1 hour ; take out, wash, and sadden with a bath of

Boil for $\frac{3}{4}$ hour.

FeSO, . . . . . . . $0.400 \mathrm{gm}$.

No. 3. $\mathrm{CuSO}_{4}$.

Same as No. 2, only sadden with

$\mathrm{CuSO}_{4}$. . . . $\quad 0.400 \mathrm{gm}$.

Boil for $\frac{3}{4}$ hour. 
No. 4. $\mathrm{SnCl}_{2}$.

Boil in a bath of

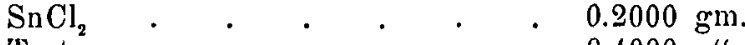

$$
\begin{aligned}
& \text { Tartar . . . . . } 0.4000 \text { " } \\
& \mathrm{HICl} \text {. . . . . q. s. }
\end{aligned}
$$

for $1 \frac{1}{2}$ hours; take out, wash, and boil in a bath of
Wood
$5.000 \mathrm{gms}$.

for I hour. Use distilled water.

No 5. $\mathrm{Al}_{2}\left(\mathrm{SO}_{4}\right)_{3}$.

Boil in the mordant for $1 \frac{1}{2}$ hours

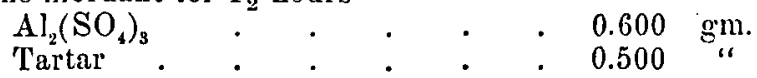

Take out, wash, and boil for $i$ hour.

Wood . . . . . . 5.000 gms.

\section{LIMA-WOOD.}

No. $10142,10148$.

Wood . . . . . 5.00 gms.

Boil for 1 hour; then take out, wash, and sadden with

Boil for $1 \frac{1}{2}$ hours.

$\mathrm{CuSO}_{4} . \quad . \quad . \quad .0 .800 \mathrm{gm}$.

No. 10141 .

Wood take out and sadden in a bath of

Boil for 1 hour.

$\mathrm{FeSO}_{4}$. . . . . . $0.500 \mathrm{gm}$.

No. 1.

$1 \frac{1}{2}$ hours, $100^{\circ} \stackrel{4}{\mathrm{C}}$.

$\begin{array}{llllllll}\text { Dye-wood } & \cdot & \cdot & \cdot & \cdot & : & 5.00 & \mathrm{gms} . \\ \mathrm{Al}_{2}\left(\mathrm{SO}_{4}\right)_{3} & \cdot & \cdot & \cdot & \cdot & \cdot & 0.400 & \mathrm{gm} . \\ \mathrm{K}_{2} \mathrm{C}_{2} \mathrm{O}_{4} & \cdot & \cdot & \cdot & \cdot & \cdot & 0.200 & \text { " }\end{array}$

Purplish slate.-No. $2(10143,10144,10149) 0.3 \mathrm{gm} . \mathrm{K}_{2} \mathrm{Cr}_{2} \mathrm{O}_{\tau}$. Wash and dye in a separate bath

Dye-wood

$1.00 \mathrm{gm}$.

Brown.-No. 3.

Dye-wood. . . . . $\quad .5 .00 \mathrm{gms}$.

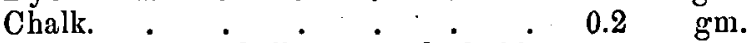

3-5 per cent. Chalk makes shade bluer.

Bluish-red.-No. 4 (10140).

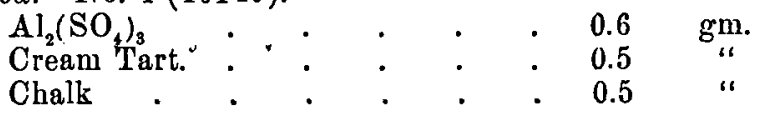


Waşh and dye in separate bath $\frac{1}{2}-1$ hour $80^{\circ}-100^{\circ} 4.0-60 \mathrm{gms}$. dye-wood; add 2-6 per ceut. Chalk. Brighter reds by adding to mordanting bath 1 per cent. $\mathrm{SnCl}_{2}$ and same amount old Fustic.

\section{CAMI-WOOD.}

Clarel-brown.-No. 1 (10120), 40 per cent. No. 2 (10121), 80 per cent.

$0.5-2.0 \mathrm{gm} . \mathrm{K}_{2} \mathrm{Cr}_{2} \mathrm{O}_{7}$ dye in separate bath $4.0-8.0 \mathrm{gms}$. dyewood; or,

Boil wool 1-2 hours in bath of $4.0-8.0 \mathrm{gms}$. of dye-wood, to a verr full brownish-red color; then in same, or, better, separate bath of $0.2 \mathrm{gm} . \mathrm{K}_{2} \mathrm{Cr}_{2} \mathrm{O}_{7} \frac{1}{2}$ hour.

Pink.-No. 3 (10122) 10 per cent. No. 4 (10123), 40 per cent. No. 5 (10124), 80 per cent.

Boil with $1.0 \mathrm{gm}$. wood $1-2$ hours and dye in $1.0 \mathrm{gm} . \mathrm{Al}_{2}\left(\mathrm{SO}_{4}\right)_{3}$ in separate bath.

40 per cent., red ; 80 per cent., deep red.

No. 1 (10125) $\mathrm{SnCl}_{2}$.

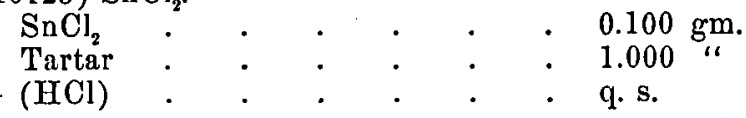

Boil for $1 \frac{1}{2}$ hours; take out, wash, and dye in a separate bath Wood

Boil for 1 hour. Use distilled water.

No. 2 (10125) CuSO.

Boil in a bath of the wood for 1 hour.

$$
\begin{aligned}
& \text { Wood . . . . . } 5.000 \mathrm{gms} \text {. } \\
& \mathrm{CaCO}_{3} . \quad . \quad . \quad . \quad .0 .100 \mathrm{gm} \text {. }
\end{aligned}
$$

Take out, wash, and sadden with

Boil for $\frac{1}{2}$ hour.

$$
\mathrm{CuSO}_{4} \cdot . \quad . \quad .0 .800 \text { " . }
$$

No. 3. FeSO,

The same as No. 2, but use FeSO $\quad$. $\quad 0.500 \mathrm{gm}$.

\section{SAPAN-WOOD.}

No. $10135,10136 . \mathrm{Sn}$ :

$$
\begin{aligned}
& \mathrm{SnCl}_{2} \text {. . . . . . } 0.100 \mathrm{gm} \text {. } \\
& \text { Tartar . . . . . } \quad . \quad 1.600 \mathrm{gms} \text {. }
\end{aligned}
$$

Boil for $1 \frac{1}{2}$ hours; take out, wash, and dye in a bath of

$$
\text { Wood . . . } 5.00 \mathrm{gms} \text {. }
$$

No lime-salts must be present. Use distilled water. 
No. 10138.

$$
\mathrm{CuSO}_{4} . \quad . \quad . \quad 0.800 \mathrm{gm} \text {. }
$$

Boil for $1 \frac{1}{2}$ honrs; take out, wash, and dye in a bath of

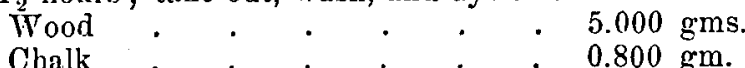

Boil for 1 hour.

NoтE.-To mordant wool efficiently with Aluminium Sulph., pre pare the following solution :-

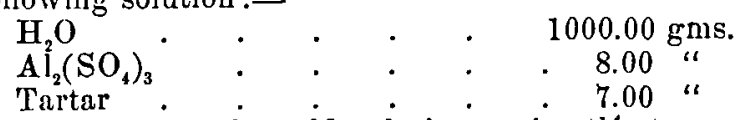

Immerse the wool in the cold solution; raise the temperature gradually to the boiling-point in the course of $1-1 \frac{1}{2}$ hours ; continue boiling $\frac{1}{2}$ hour longer, then wash well.

Cochineal.

Reddish-purple.-No. 1 (10065).

$$
\mathrm{CuSO}_{4} \cdot{ }_{1.00 \mathrm{gm}}
$$

Boil $\frac{3}{4}$ hour; take out and wash well.

$$
\text { Cochineal . . . . } 1.2 \text { gms. }
$$

in separate bath. Boil 1 hour.

Purplish slate.-No. 2 (10061).

$$
\begin{aligned}
& \mathrm{FeSO}_{4} \text {. } \quad \text {. . . } 0.8 \mathrm{gm} \text {. } \\
& \text { Tartar . . . . . } 2.00 \mathrm{gms} \text {. }
\end{aligned}
$$

Boil $\frac{3}{4}$ hour ; take out, wash, dye in separate bath for 1 hour at $100^{\circ} \mathrm{C}$.

Cochineal . . . . . $1.2 \mathrm{gms}$.

Purple.-No. 3 (10064).

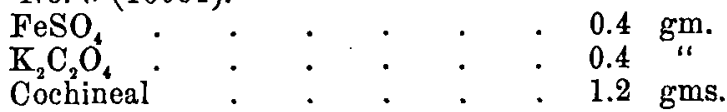

Enter flannel at $50^{\circ} \mathrm{C}$; raise to boil; boil 1 hour.

Cochineal Spirits.-No. 1 (10050).

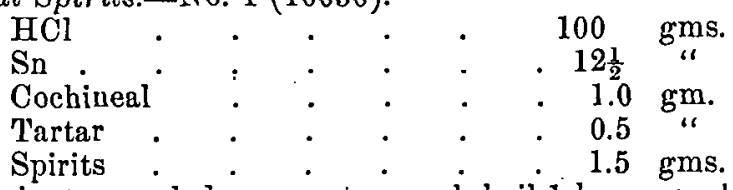

Boil 20 minutes, cool down; enter wool, boil 1 hour; soak over night.

No. 10051. Same, using 0.5 dye, 0.3 Tartar, 0.8 cc. Spirits. 
No. 10052. Same, using 0.1 dye, 0.1 Tartar, 0.2 cc. Spirits.

No. 2 (10061, 10062).

$$
\begin{aligned}
& \mathrm{FeSO}_{4} \text {. . . . . . } 0.8 \mathrm{gm} \text {. } \\
& \text { Tartar . . . . . . } 0.2 \text { " }
\end{aligned}
$$

Boil $\frac{3}{4}$ hour; take out, wash, and dye in separate bath for 1 hour Cochineal . . . . . $1.2 \mathrm{gms}$.

Cochineal crimson.

$$
\begin{array}{llllllll}
\mathrm{Al}_{2}\left(\mathrm{SO}_{4}\right)_{3} & \cdot & \ddots & \cdot & \cdot & \cdot & \cdot & 0.4 \\
\text { Tartar } & \mathrm{gm} . & 0.5 & \text {. }
\end{array}
$$

Mordant; wash and dye $1-1 \frac{1}{2}$ hours
Cochineal . . . 0.8 . 0

Scarlet.-No. 1.

Mordant $1-1 \frac{1}{2}$ hours with $0.6 \mathrm{gm} . \mathrm{SnCl}_{2}, 0.4 \mathrm{gm}$. Tartar; wash, and dye in $0.5 \mathrm{gm}$. Cochineal $1-1 \frac{1}{4}$ hours; enter wool in mordanting and dye-baths at $50^{\circ} \mathrm{C}$. and raise gradually to boiling.

No. 2.

Bath $\frac{1}{2}$ full of water.

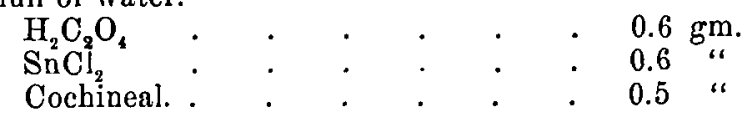

Boil 5-10 minutes; fill bath with cold $\mathrm{H}_{2} \mathrm{O}$; introduce wool; heat to boiling $\frac{3}{4}-1$ hour; boil $\frac{1}{2}$ bour.

Use $\mathrm{SnCl}_{2}$ in solution. A moderate amount of $\mathrm{HCl}$ is advantageous.

Cochineal Spirits.-No. 10050.

$$
\begin{aligned}
& \text { Cochineal (10014) . . . . } 1.000 \mathrm{gm} \text {. } \\
& \text { Tin Spirits (10040) . . . . . . } 0.100 \text { “ } \\
& \text { Water, dist. . . . . . } 1.5 \text { liters. }
\end{aligned}
$$

Mix the Cochineal (ground) with water to a thin paste; add Tin Spirits, dilute with water, heat to boiling, and continue 15 minutes; then cool to $180^{\circ} \mathrm{F}$., enter wool, raise to boiling, and continue for I hour, or until the bath is exhausted; allow to cool in the bath, then take out and wash in warm water.

No. $10059,10060$.

Cochineal with $\mathrm{K}_{2} \mathrm{Cr}_{2} \mathrm{O}_{7} 0.2 \mathrm{gm}$. and $0.3 \mathrm{gm}$. $\mathrm{H}_{2} \mathrm{SO}_{4}$ conc. gives purple.

Cochineal crimson.- No. 1 (10053).

$$
\mathrm{Al}_{3}\left(\mathrm{SO}_{4}\right)_{3} \cdot \cdot \cdot \cdot \cdot 0.4 \mathrm{gm} .
$$

Boil 1-1 $\frac{1}{2}$ hours. 
No. 2.

$$
\text { Cochineal . . . . } \quad \text {. } 8.0-15.0 \text { gms. }
$$

Cochineal scarlet.-No. $2(10054,10055)$.

First method: Mordant $1-1 \frac{1}{2}$ hours with $0.6 \mathrm{gm}$. $\mathrm{SnCl}_{2}$ cryst., 0.4 Tartar; wash, and dye in $1.2 \mathrm{gms}$. Cochineal $1-1 \frac{1}{4}$ hours ; enter wool in mordanting and dye-baths at $50^{\circ} \mathrm{C}$. and raise gradually to boiling.

No. 3 (10056).

Second method: Bath $\frac{1}{2}$ full of water

$$
\begin{aligned}
& \begin{array}{lllllll}
\text { Oxalic Acid } & \cdot & \cdot & \cdot & \cdot & . & 0.8 \mathrm{gm} . \\
\mathrm{SnCl}_{2} & \cdot & \cdot & \cdot & . & \cdot & 0.6
\end{array} \\
& \text { Ground Cochineal. . . . . } 1.2 \mathrm{gms} \text {. }
\end{aligned}
$$

Boil for 5-10 minutes; then fill bath with cold water, introduce wool, heat to boiling-point ( $\frac{3}{4}-1$ hour), and boil $\frac{1}{2}$ hour. Bath not exhausted in this method.

Deficiency of tin causes dull bluish-red; an excess makes the scarlet paler.

\section{LAC.}

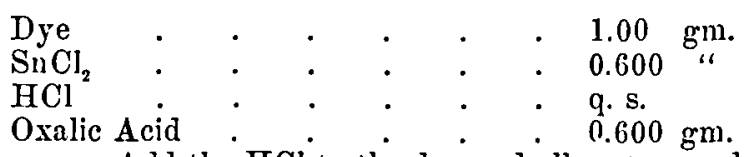

Boil $1 \frac{1}{2}$ hours. Add the HCl to the dye and allow to stand over night.

Chromium.

$$
\mathrm{K}_{2} \mathrm{Cr}_{2} \mathrm{O}_{7} \text {. . . . . } \quad 0.3 \mathrm{gm} \text {. }
$$

Same amount of Lac as above. Mordant; wash, and dye in separate bath $1 \frac{1}{2}$ hours.

Alumina.

$$
\mathrm{Al}_{2}\left(\mathrm{SO}_{4}\right) \cdot \quad \cdot \quad \cdot \quad \cdot \quad \cdot \quad \cdot 0.4 \mathrm{gm} .
$$

- Mordant; wash, and dye.

Copper.

$\mathrm{CuSO}_{4} \cdot$..$\quad \cdot$. $1.0 \mathrm{gm}$.

Iron.

$\begin{array}{lllllllll}\mathrm{FeSO}_{4} & \cdot & \cdot & \cdot & \cdot & . & . & 0.8 \mathrm{gm} . \\ \text { Tartar } & \cdot & \cdot & \cdot & \cdot & \cdot & \cdot & 2.0 & \mathrm{gms} .\end{array}$ 
Scarlet Lac Spirits.

Solution-

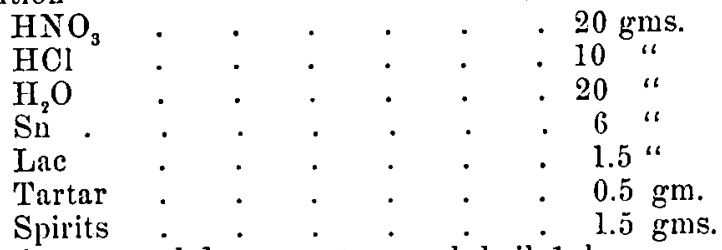

Boil 20 minutes, cool down; enter wool, boil 1 hour; soak over night.

No. $2(10068,10069)$.

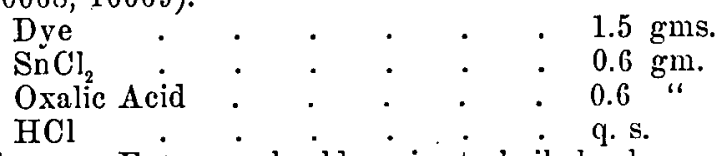

Boil 1 $\frac{1}{2}$ hours. Enter wool cold ; raise to boil slowly.

Note well. - Add $\mathrm{HCl}, 4$ or 5 drops, to about 25 cc. $\mathrm{H}_{2} \mathrm{O}$; rub this up with the dye and allow to stand over night.

\section{MADDER.}

Red.-No. 1 (10077).

Mordant first-

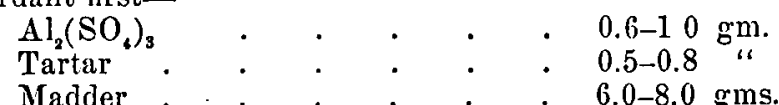

Begin dyeing at $40^{\circ} \mathrm{C}$; ; raise to $80^{\circ}-100^{\circ} \mathrm{C}$. during $\underset{1}{\mathrm{i}}$ hour, continue 1 hour, wash, and dry.

The shade is brownish-red, brightened by adding small amount $\mathrm{SnCl}_{2}$ to dye-bath at close of operation; better colors, 1-2 per cent. weight of Madder in Chalk.

The best results are obtained at $80^{\circ} \mathrm{C}$; add $0.6 \mathrm{gm}$. Sumach to bring ont color.

Orange.-No. 2 (separate bath).

$$
\begin{aligned}
& \mathrm{SnCl}_{2} \quad \text {. } \quad . \quad \text {. } \quad \text {. } \quad \text {. } \quad \text {. } 0.8 \mathrm{gm} \text {. } \\
& \text { Tartar . . . . . . . . } 0.4 \text { " } \\
& \text { Madder : } \quad . \quad+\quad . \quad+\quad .6 .0 \mathrm{gms} \text {. }
\end{aligned}
$$

No. 2 a. Same (single bath).

$$
\begin{array}{lllllll}
\mathrm{SuCl}_{2} & \cdot & \cdot & \cdot & \cdot & \cdot & 0.4 \mathrm{gm} \\
\mathrm{H}_{2} \mathrm{C}_{6} \mathrm{H}_{4} \mathrm{O}_{6} & \cdot & \cdot & \cdot & \cdot & \cdot & 0.2
\end{array}
$$

Brown.

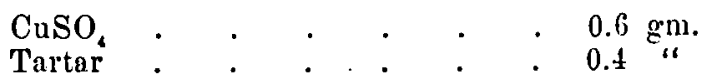

Mordant and dye. 
Dark brown.

Mordant and dye.

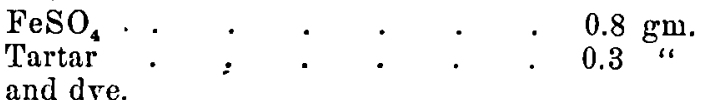

Reddish-brown.-No. 10077.

$\mathrm{K}_{2} \mathrm{Cr}_{2} \mathrm{O}_{7} \cdot$. . . $0.3 \mathrm{gm}$.

Mordant; wash, and dye in separate bath of Madder. . . . $6.0 \mathrm{gms}$.

No. 10076.

Dye with Madder alone at $80^{\circ} \mathrm{C}$., using
Madder
. . $6.00 \mathrm{gms}$.

In the second batch no Sumach was used; all samples were treated in a bran-bath for 5 minutes at $70^{\circ} \mathrm{C}$. to brighten and fix; used distilled water and Chalk.

Neutral bath.

Orchil (Cudbear).

Acid bath with $\mathrm{H}_{2} \mathrm{SO}_{4}$.

Alkaline bath with soap solution.

Anatio.

Dye at $50^{\circ} \mathrm{C}$., with soap for pale shades.

Dye at $80^{\circ}-100^{\circ} \mathrm{C}$., without addition, for dark shades.

No. 1 (10233).

Dye
Add soap; dye at $50^{\circ} \mathrm{C}$. (use soap solution).

No. 2 (10234).

Dye . . . . . . $4.00 \mathrm{gms}$.

Same as above.

No. 3 (10235).

No soap.
Dye

No. 4 (10236).

No soap.
Dye
$8.00 \mathrm{gms}$.

WELD.

Old gold.-No. 1 (10248).

$$
\mathrm{K}_{2} \mathrm{Cr}_{2} \mathrm{O}_{7} \cdot \quad \cdot \quad \cdot \quad \text {. } 0.2 \mathrm{gm} \text {. }
$$


Mordant; wash, and dye in separate bath

$\begin{array}{llllllll}\text { Weld } & \cdot & \cdot & \cdot & \cdot & \cdot & \cdot & 6.0 \mathrm{gms} \\ \text { Chalk } & \cdot & \cdot & \cdot & \cdot & \cdot & \cdot & 0.3 \mathrm{gm} .\end{array}$

No. $2(10250)$.

$\mathrm{Al}_{2}\left(\mathrm{SO}_{4}\right)_{3} \cdot$. . . $\quad 0.4 \mathrm{gm}$.

Mordant; wash, and dye in separate bath with

Weld . . . . . $7.5 \mathrm{gms}$.

1 hour at $80^{\circ}-90^{\circ} \mathrm{C}$.

No. 3.

Mordant; wash, and dye in separate bath $\mathrm{SnCl}_{q} \cdot 0.8 \mathrm{gm}$. Weld . . . . . $7.5 \mathrm{gms}$.

No. 4 (10249).

Same, with

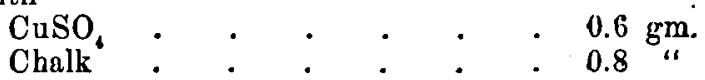

No. 5.

Same, with

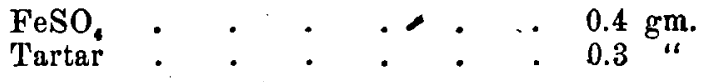

Old Gold.

$\mathrm{K}_{2} \mathrm{Cr}_{2} \mathrm{O}_{7} \cdot \quad \cdot \quad \cdot \quad \cdot \quad \cdot \quad \cdot 0.2 \mathrm{gm}$.

Mordant and dye in separate bath with $0.6 \mathrm{gm}$. Weld; add $3.0 \mathrm{gms}$. Chalk to dye-bath.

Yellow.-Mordant 1-2 hours with $0.4 \mathrm{gm} . \mathrm{Al}_{2}\left(\mathrm{SO}_{4}\right)_{3}$; wash, and dye in separate bath with decoction of $5.0-10.00$ gms. Weld for 20-60 minutes at $80^{\circ}-90^{\circ} \mathrm{O}$.

Prepare bath just before dyeing; chop the Weld, put in bags, and boil in soft water $\frac{1}{2}-1$ hour; add $0.4 \mathrm{gm}$. Chalk before dyeing.

Brighter yellows are obtained by mordanting with $0.8 \mathrm{gm}$. $\mathrm{SnCl}_{2}$. Also, single bath similar to cochineal scarlet gives bright yellows.

Yellowish-olive.-Mordant with $0.6 \mathrm{gm}$. $\mathrm{CuSO}_{4}$; add $0.2-0.8 \mathrm{gm}$. $\mathrm{CaCO}_{3}$ or $0.4 \mathrm{gm}$. FeSO, and $0.3 \mathrm{gm}$. Tartar, with Chalk.

Use water-bath.

\section{Fustic.}

No. $1(10169,10170)$.

$\mathrm{K}_{2} \mathrm{Cr}_{2} \mathrm{O}_{7} \cdot$. $\cdot$. $0.4 \mathrm{gm}$.

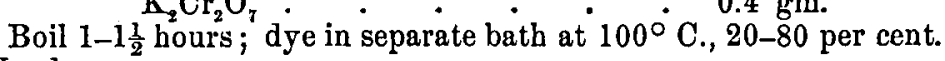
Wood.

This will yield a brownish or olive-yellow.

Vox. XI.-12 
Yellow.-No. 2 (10171, 10172) (single bat $\overline{\mathrm{h}}$ ).

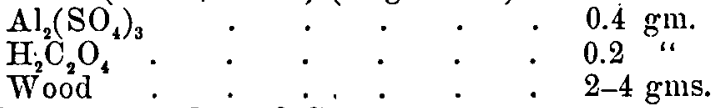

Dye $1-1 \frac{1}{2}$ hours at $80^{\circ}-100^{\circ} \mathrm{C}$.

The addition of Tartar deepens, but dulls the color.

Yellow.-N.o. $3(10173,10174,10175)$.

$\mathrm{Al}_{2}\left(\mathrm{SO}_{4}\right)_{3} \cdot{ }_{1} \cdot 0.8 \mathrm{gm}$.

Mordant $1-1 \frac{1}{2}$ hours at $100^{\circ} \mathrm{C}$. and wash; dye-bath, $2-4 \mathrm{gms}$. Wood; work in this for $\frac{1}{2}-\frac{3}{4}$ hour at $80^{\circ}-90^{\circ} \mathrm{C}$.

By using 0.2-0.3 $\mathrm{gm}$. SnCl ${ }_{2}$ crystals with the alum, much brighter colors can be obtained. (See No. 4.)

Yellow.-No. 4 (10176, 10177, 10178).

$\begin{array}{llllll}\mathrm{Al}_{2}\left(\mathrm{SO}_{4}\right)_{3} & \cdot & \cdot & \cdot & \cdot & 0.8 \mathrm{gm} . \\ \mathrm{SnCl}_{2} & . & . & . & 0.3\end{array}$

Enter into bath at $50^{\circ} \dot{C}$., heat gradually to $100^{\circ}$ for $1-1 \frac{1}{2}$ hours, and dye as in No. 3.

Yellow.-No. 5 (10179, 10180). $\begin{array}{llllllll}\mathrm{SnCl}_{2} & \cdot & \cdot & \cdot & \cdot & \cdot & \cdot & 0.8 \mathrm{gm} . \\ \text { Tartar } & \cdot & \cdot & \cdot & \cdot & \cdot & \cdot & 0.8\end{array}$

Treat $1-1 \frac{1}{2}$ hours at $100^{\circ} \mathrm{C}$., wash, and dye in a bath of Wood treating 30-40 minutes at $80^{\circ}-100^{\circ} \dot{\mathrm{C}}$.

Yellow.-No. 6 (10181) (single bath).

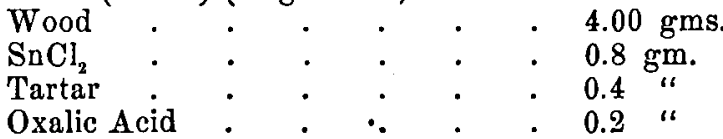

Avoid prolonged dyeing, especially at $100^{\circ} \mathrm{C}$., as the tannin injures the colors; to avoid this trouble use solution of glue to extent of 4-8 per cent. of the dye-wood.

Olives.-No. 7 (10182) (single bath).

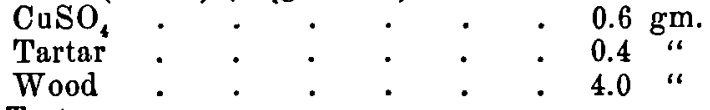

Or omit Tartar.

No. 8 (10183).

Mordunt and dye, using same bath.

No. $9(10184,10185)$.

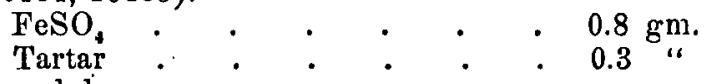

Mordant and dye. 
No. $10(10186,10187)$ (single bath).

Use no Tartar.

Brownish or olive-yellow.-No. 1.

$$
\mathrm{K}_{2} \mathrm{Cr}_{2} \mathrm{O}_{\mathrm{T}} \cdot \cdot \quad \cdot \quad \cdot \quad \cdot 400 \mathrm{gm} \text {. }
$$

Boil 1-1 $\frac{1}{2}$ bours and dye in separate hatb $1-1 \frac{1}{2}$ bours at $100^{\circ} \mathrm{C}$, 2.0-8.0 gms. dye.

Yellow.-No. 2 (single bath).

$1-1 \frac{1}{2}$ hours at $80^{\circ}-100^{\circ} \mathrm{C}$.

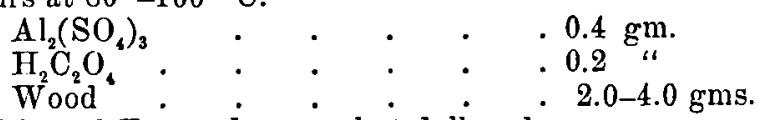

The addition of Tartar deepens, but dulls color.

No. 3.

Mordant $1-1 \frac{1}{2}$ hours with $0.8 \mathrm{gm} . \mathrm{Al}_{2}\left(\mathrm{SO}_{4}\right)_{3}$, wash, and dye $\frac{1}{2}-\frac{3}{4}$ hour at $80^{\circ}-90^{\circ} \mathrm{C}$., $2.0-4.0 \mathrm{gms}$. dye.

By using $0.2-0.3 \mathrm{gm}$. $\mathrm{SnCl}_{2}$ with the alum much brighter colors are obtained.

No. 3.

Mordant $1-1 \frac{1}{2}$ hours with $0.8 \mathrm{gm}$. $\mathrm{SnCl}_{2}$ crystals and $0.8 \mathrm{gm}$. Tartar, wash, and dye in separate bath $30-40$ minutes at $80^{\circ}-100^{\circ}$ C., 2.0-4.0 gms. Wood.

\section{Quercitron.}

Use Flavin; $1 \mathrm{Fl}$. $=16$ Quer.

Canary-yellow.-No. 1 (10194, 10196).

Boil $\frac{1}{2}-\frac{3}{4}$ hour in solution of .

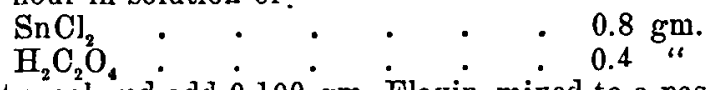

Take out wool and add $0.100 \mathrm{gm}$. Flavin mixed to a paste; boil 5-10 minutes, re-enter wool, and continue to boil $\frac{1}{2}-1$ hour.

Oxalic acid may be replaced by Tartar or Tartaric Acid. Nore $\mathrm{SnCl}_{2}$ yields brighter and redder shades.

Bright orange.-No. 2 (10195, 10197).

Same as above, using

Flavin . . . . . . $0.8 \mathrm{gm}$.

Quercitron Bark.

Olive-yellow.-No. 3 (10198, 10199).

$$
\mathrm{K}_{2} \mathrm{CrO}_{27} \cdot \dot{0} \quad \dot{0} \quad 0.3 \mathrm{gm} \text {. }
$$

Mordant $1-1 \frac{1}{2}$ hours, wash, and dye in separate bath Quercitron . . . . . $4.0 \mathrm{gms}$. 
No. 4. Same as above; use Quercitron . . . . . $8.0 \mathrm{gms}$.

Yellow.-No. 5 (10200) (single bath).

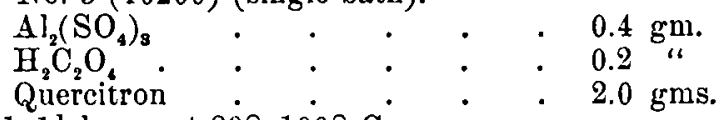

Dye for $1-1 \frac{1}{2}$ hours at $80^{\circ}-100^{\circ} \mathrm{C}$.

No. 6 (10201).

Mordant 1-1 $\frac{1}{2}$ hours with $0.8 \mathrm{gm} . \mathrm{Al}_{2}\left(\mathrm{SO}_{4}\right)_{3}$, wash, and dye in separate bath $\frac{1}{2}-\frac{3}{4}$ hour at $80^{\circ}-90^{\circ}$ C., 4.0 gms. Bark.

No. 7 (10202).

$$
\mathrm{CuSO}_{4} \cdot \cdot \quad \cdot \quad \cdot 0.6 \mathrm{gm} \text {. }
$$

Mordant, wash, and dye in separate bath of

$$
\text { Quercitron . . . . } 4.0 \mathrm{gms} \text {. }
$$

for $\frac{1}{2}-\frac{3}{4}$ hour at $80^{\circ}-90^{\circ} \mathrm{C}$.

Quereitron Spirits._-No. 10203.

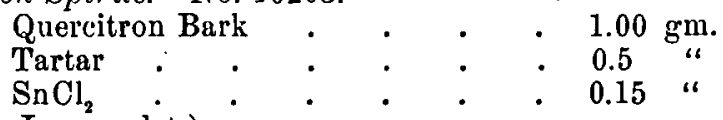

(Same as Lac scarlet.)

Boil 20 minutes, cool down, enter wool, and boil 1 hour.

The bark was put in a bleeding bag and soaked over night.

\section{- Sumach.}

No. 1. Reddish-brown.-No. 10188.

$\mathrm{K}_{2} \mathrm{Cr}_{2} \mathrm{O}$, $\cdot \dot{0} \cdot 0.3 \mathrm{gm}$.

Mordant $1-1 \frac{1}{2}$ hours, wash, and dye in separate bath.

Sumach . . . . $4.0 \mathrm{gms}$.

Avoid too high heat and add glue solution.

Yellow.-No. 2 (10189).

$\begin{array}{llllllllll}\mathrm{SnCl}_{2} & \cdot & \cdot & \cdot & \cdot & \cdot & \cdot & 0.8 \mathrm{gm} . \\ \mathrm{H}_{2} \mathrm{C}_{2} \mathrm{O}_{4} & \cdot & \cdot & \cdot & \cdot & \cdot & - & 0.4 & \end{array}$

Mordant $\frac{1}{2}-\frac{3}{4}$ bour and take out wool ; add 4 gms. Sumach, boil 10 minutes, re-enter wool, and boil $\frac{1}{2}-1$ hour.

No. 3 (10190).

$\mathrm{Al}_{2}\left(\mathrm{SO}_{4}\right)_{3} \quad \cdot \cdot \cdot \quad \cdot \quad \cdot 0.8 \mathrm{gm}$.

Mordant $1-1 \frac{1}{2}$ hours, wash, and dye in separate bath of

Sumach. . . . . $4.0 \mathrm{gms}$. $\frac{1}{2}-\frac{3}{4}$ hour at $80^{\circ}-90^{\circ} \mathrm{C}$. 
No. 4 (10191) (single bath).

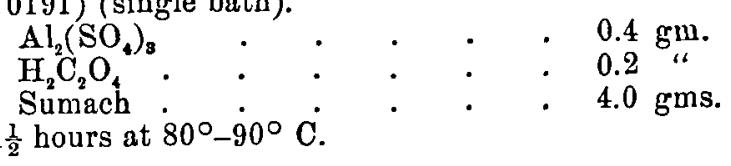

No. 5 (10193).

$$
\begin{aligned}
& \mathrm{FeSO}_{4} \quad \cdot \quad \cdot \quad \cdot \quad \cdot \quad \cdot 0.8 \mathrm{gm} \text {. } \\
& \text { Tartar . . . . . . } 0.3 \text { " }
\end{aligned}
$$

Mordant, wash, and dye in separate bath of

$$
\text { Sumach. . . . } 4.0 \text { gms. }
$$

for $1-1 \frac{1}{2}$ hours at $80^{\circ}-90^{\circ} \mathrm{C}$.

No. 6 (10192).

CuSO, . . . . $0.6 \mathrm{gm}$.

Mordant, wash, and dye in separate batb of

$$
\text { Sumach. . . } 4.0 \mathrm{gms} \text {. }
$$

for $1-1 \frac{1}{2}$ hours at $80^{\circ}-90^{\circ} \mathrm{C}$.

\section{Persian Berries.}

No. $1(10214,10215,10216,10217)$.

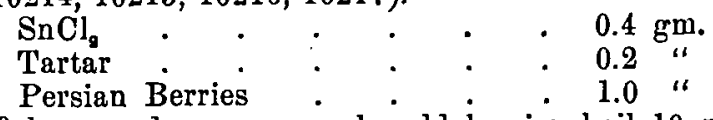

Boil $\frac{1}{2}-\frac{3}{4}$ hour and remove wool; add berries, boil 10 minutes, and add equal bulk of cold water ; remove to water-bath, enter wool, and treat 1 hour at $80^{\circ}-90^{\circ} \mathrm{C}$.

No. $2(10218,10219,10220,10221)$.

Same, using

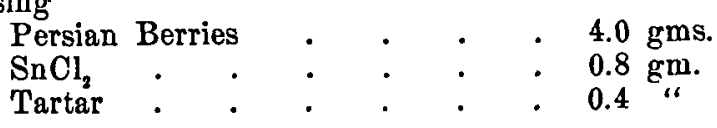

No. 3 (10222, 10223, 10224).

Same as No. 1 ; use $0.2 \mathrm{gm}$. $\mathrm{H}_{2} \mathrm{C}_{2} \mathrm{O}_{4}$ instead of Tartar.

No. 4.

Same as No. 2 ; use $\mathrm{H}_{2} \mathrm{C}_{2} \mathrm{O}_{4}$ instead of Tartar.

Yellow.-No. 5 (10212).

$$
\mathrm{Al}_{2}\left(\mathrm{SO}_{4}\right)_{3} \quad \cdot \quad \cdot \quad \text { : } \quad \begin{aligned}
& 0.8 \mathrm{gm} . \\
& 4.0 \mathrm{gms} .
\end{aligned}
$$

Treat as in No. 1. 
No. 6 (10213).

$\mathrm{FeSO}_{4}$. . . . . $0.4 \mathrm{gm}$.

Tartar . . . . . . . . 0.3 "

Treat as in No. 1.

TURMERIC.

Yellow.-No. 1 (10084).

$\mathrm{Al}_{2}\left(\mathrm{SO}_{4}\right)_{3}$. . . . $0.8 \mathrm{gm}$.

Mordant and dye.

Turmeric $\quad . \quad: \quad . \quad \cdot 4.0 \mathrm{gms}$.

Olive.-No. 2 (10085).

Same as No. 1 .

$\mathrm{K}_{2} \mathrm{Cr}_{2} \mathrm{O}_{7}$. . . . . $0.3 \mathrm{gm}$.

Turmeric . . . . . $4.0 \mathrm{gms}$.

Brown.-No. 3 (10086).

$\mathrm{FeSO}_{4} \cdot$. . . . $0.8 \mathrm{gm}$.

Turmeric . . . . . $4.0 \mathrm{gms}$.

Same as No. 1.

Yellow.-No. 4 (10083).

Turmeric . . . . . $4.0 \mathrm{gms}$.

Same as No. 1.

Yellow.-No. 5 (10087).

$\mathrm{SnCl}_{2}$. . . . . . $0.4 \mathrm{gm}$.

Turmeric . . . . . $4.0 \mathrm{gms}$.

Same as No. 1. .

No. 6 (10088).

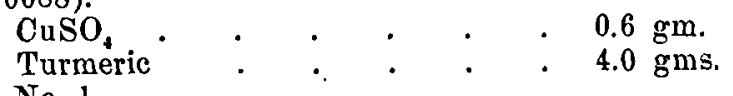

Same as No. 1.

BARBERRY Roox.

No. 1 (10089) (alkaline bath).

$\mathrm{K}_{2} \mathrm{Cr}_{2} \mathrm{O}_{7} \cdot 0.3 \mathrm{gm}$.

Mordant, wash, and dye in separate bath of Barberry Root . . . . $5.0 \mathrm{gms}$.

No. $2(10090)$.

Mordant, wasb, and dye in separate bath of Barberry Root

$0.8 \mathrm{gm}$ :

$5.0 \mathrm{gms}$. 
No. 3 (10093).

$\mathrm{SnCl}_{2}$. $\quad . \quad$. . $\quad .0 .8 \mathrm{gm}$.

$\mathrm{HCl}$. . . . . q.

Mordant, wash, and dye in separate bath of

Barberry Root . . . $\quad$. 5.0 gms.

No. 4 (10091).

$\mathrm{CuSO}_{4}$. . . . $0.6 \mathrm{gm}$.

Mordant, wash, and dye in separate bath of Barberry Root . . . . $5.9 \mathrm{gms}$.

No. 5 (10092).

$\mathrm{FeSO}_{4}$..$\quad \cdot \quad \cdot \quad \cdot \quad 0.4 \mathrm{gm}$.

Tartar : . . . . . 0.3 "

Mordant, wash, and dye in separate bath of

Barberry Root . . . . $5.0 \mathrm{gms}$.

Catechu.

No. 1 (10205).

Catechu . . . . . $2.00 \mathrm{gms}$.

Boil 1-1 $\frac{1}{2}$ hours; sadden in separate bath of for $\frac{1}{2}$ hour at $80^{\circ}-100^{\circ} \mathrm{C}$.

$\mathrm{K}_{2} \mathrm{Cr}_{2} \mathrm{O}_{7} \cdot \mathrm{C}^{\circ} \cdot{ }^{\circ} \cdot 0.4 \mathrm{gm}$.

No. 2 (10206).

Same as No. 1, but sadden in bath of

$\mathrm{CuSO}_{4} \cdot . \quad . \quad .0 .6 \mathrm{gm}$.

No. 3 (10207).

Same as No. 1, but sadden in bath of

$\mathrm{FeSO}_{4} \cdot$. $\cdot$. $\quad$. $0.4 \mathrm{gm}$.

No. 4 (10208).

Same as No. 1, but sadden in bath of $\mathrm{Al}_{2}\left(\mathrm{SO}_{4}\right)_{3} \quad \cdot \quad \cdot \quad \cdot \quad \cdot \quad \cdot 1.00 \mathrm{gm}$.

No. 5 (10209).

Same as No. 1, but sadden in bath of $\mathrm{SnCl}_{2}$. $. \quad . \quad . \quad .0 .4 \mathrm{gm}$.

LOGWOOD.

Gray.-No. 10094.

Logwood $\cdot \quad \vdots \quad \cdot 0.5 \mathrm{gm}$.

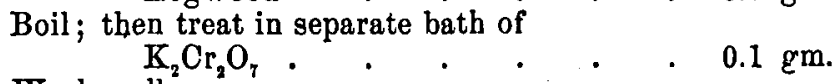

Wash well. 
Purple.-No. 10095, 10099.

Mordant the wool with

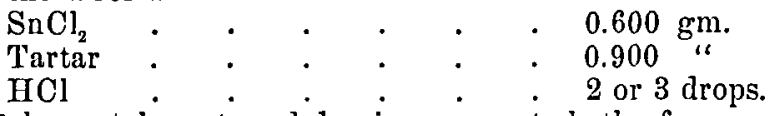

Boil for 1 hour, take out, and dye in a separate bath of

$$
\begin{array}{llllll}
\text { Logwood } & \cdot & \cdot & \cdot & . & 1.5 \mathrm{gms} . \\
\text { Distilled water } & \cdot & \cdot & \cdot & \cdot & \text { q. s. }
\end{array}
$$

Blue.-No. 10096, 10097.

Mordant for $1-1 \frac{1}{2}$ hours at $100^{\circ} \mathrm{C}$. in bath of $\begin{array}{lllllll}\mathrm{Al}_{2}\left(\mathrm{SO}_{4}\right)_{3} & \cdot & \cdot & \cdot & \cdot & \cdot & 0.4 \mathrm{gm} . \\ \operatorname{Tartar}^{2} & \cdot & . & \cdot & \cdot & \cdot & 0.5\end{array}$

Wash well and dye in separate bath of

$$
\begin{array}{llllll}
\text { Chip Logwood } & \cdot & \cdot & \cdot & \cdot & 1.5-3.0 \mathrm{gms} \\
\text { Chalk } & \cdot & \cdot & \cdot & \cdot & 0.2-0.3 \mathrm{gm} \text {. }
\end{array}
$$

for $1-1 \frac{1}{2}$ hours at $100^{\circ} \mathrm{C}$.

Blue.-No. 10098 (using another mordant).

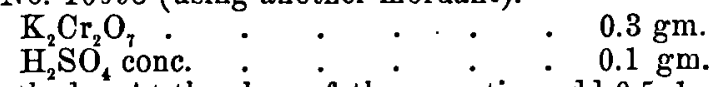

Same method. At the close of the operation add 0.5-1 per cent. $\mathrm{SnCl}$.

Brighest blues are dyed at $90^{\circ} \mathrm{C}$.

Black.-Iron-black No. 1.

Mordant for $1 \frac{1}{2}-2$ hours in bath of

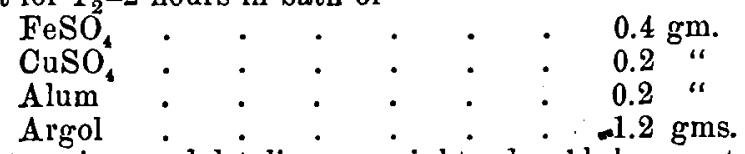

Take out, wring, and let lie over night; dye $1 \frac{1}{2}$ hours at $100^{\circ}$ C. in $4.0-5.0 \mathrm{gms}$. Logwood.

No. 2. Black.

Boil wool 1 hour with decoction of $4.0-5.0 \mathrm{gms}$. I $40 \mathrm{~g}$ wood and $0.5-1.0 \mathrm{gm}$. Fustic, lift, and cool bath; add $0.4-0.6 \mathrm{gm}$. FeSO, and $0.2 \mathrm{gm}$. CuSO, re-enter wool, raise to $100^{\circ} \mathrm{C}$. in $\frac{3}{4}$ of an hour, and boil $\frac{1}{2}$ hour longer.

Black.-No. 10100.

Mordant $1-1 \frac{1}{2}$ hours at $100^{\circ} \mathrm{C}$. in bath

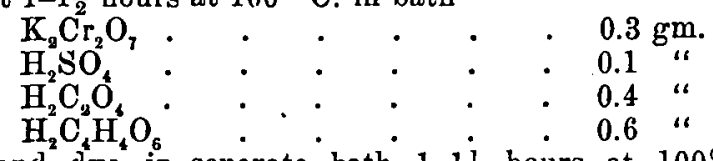

Wash, and dye in separate bath $1-1 \frac{1}{2}$ hours at $100^{\circ} \mathrm{C}$. of $3.5-4.0 \mathrm{gms}$. Logwood and $0.5 \mathrm{gm}$. of old Fustic; finally pass through a warm bath of 0.5 per cent $\mathrm{K}_{2} \mathrm{Cr}_{2} \mathrm{O}_{7}$, using Oxalic Acid. We can recommend this bath as giving fine results. 
Black on Yarn.

Mordant in bath of

$$
\mathrm{K}_{2} \mathrm{Cr}_{2} \mathrm{O}_{7} \dot{\mathrm{g}} 0.2 \mathrm{gm} \text {. }
$$

for $1 \frac{1}{2}$ hours at $100^{\circ} \dot{C}$., drain, and dye in bath of

Logwood Extract, 51 ${ }^{\circ}$ Tw.

$1.50 \mathrm{gms}$.

for $2 \frac{1}{2}$ hours at $100^{\circ} \mathrm{C}$., bath should be acid with Acetic Acid; allow to cool over night in bath, wash, and dry. Results are very good.

The dyeing with indigo on a small scale not proving successful, is omitted; the best results, however, may be obtained with the sulphite vat.

The following recipes from a practical American wool-dyer are added to this article with the hope that they may prove of value to some of the readers :-

\section{Recipes to Dye Wool Buack.}

No. I. (100 pounds clean Wool.)

Prepare with

$$
\begin{aligned}
& \text { Blue Vitriol }\left(\mathrm{CuSO}_{4}\right) \quad \cdot \quad \cdot \quad \cdot \quad \cdot \quad 1 \frac{1}{2} \text { pounds. } \\
& \text { Copperas }\left(\mathrm{FeSO}_{4}\right) \cdot \mathrm{CSO}_{4} \text { pounds. }
\end{aligned}
$$

Boil wool $1 \frac{1}{2}$ hours, then take out of the tub and drain; throw away this liquor.

Color with

$$
\begin{array}{llllr}
\text { Chip Fustic } & \cdot & \cdot & \cdot & 10 \text { pounds. } \\
\text { Chip Logwood } & \cdot & \cdot & \cdot & 15-35 \text { pounds. }
\end{array}
$$

The quantity of Logwood depends upon how intense a color is wanted.

'Boil chips in a bleeding bag 2 hours before putting in the wool; boil wool in this liquor $1 \frac{1}{2}$ hours, turn off steam, and let the wool remain in the liquor until it cools-2 hours or longer; then drain off the liquor.

No. 2.

Prepare with

Bichromate of Potash $\left(\mathrm{K}_{2} \mathrm{Cr}_{2} \mathrm{O}_{7}\right)$. 2 pounds.

Boil wool $1 \frac{1}{2}$ hours, then take it out of the tub to drain, and throw away the liquor.

Color with

$$
\text { Chip Logwood . . . 15-30 pounds. }
$$

The quantity depends upon how intense a shade is required.

Boil chips in bleeding bag 2 hours and treat wool as in recipe No. 1.

Where there is time, permit the wool to remain in the preparation (in either recipe) 2 hours after it is boiled, and let the liquor cool before draining it off; the wool is of softer feeling than if pushed through quickly. 


\section{Scarlet Lac Dye Spirits.}

$$
\begin{aligned}
& \text { Nitric Acid . . . . . } 2 \text { parts. } \\
& \text { Muriatic Acid . . . . . . } 1 \text { part. } \\
& \text { Water . . . . . . } 2 \text { parts. }
\end{aligned}
$$

Slowly add 2 ounces of feathered Tin to each pound of this liquid.

If the Tin be added in too great a quantity at once, it will fire the Spirits, precipitate Oxide of Tin, and render the spirits useless. It generally takes about 2 days to make good Lac Spirits.

For 100 pounds of wool (clean) :-

15 pounds of Lac Dye, 5 pounds of White Tartar, and 5 quarts (imperial) of above Spirits.

Boil solution 20 minutes, cool off a little, enter wool, and boil 1 hour ; shut off steam and let it soak at least 3 hours, then rinse (if yarn, rinse in cold water; if wool, rinse in water at $100^{\circ} \mathrm{F}$.).

Use more or less Lac Dye, according to shade.

\section{Cochineau Scarlet.}

Same as Lac Dye, with the exception that the Spirits are entirely of Muriatic Acid, with 2 ounces of Tin to each pound of acid, ana the Tin may be added all at once without danger.

Use one-tbird less Cochineal than Lac Dye.

\section{YeLLOW (Quercitron).}

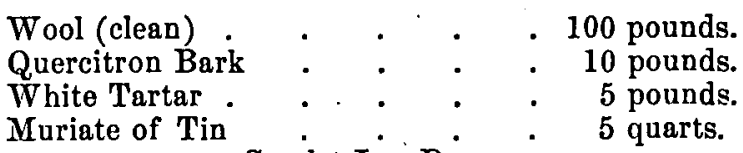

Treat in same manner as Scarlet Lac Dye.

There is no yellow colored with Fustic nowadays, and Welds are only used on silk.

\section{INDIGO-BLUE.}

There can be no recipe given for indigo-blue that would be of any service on a small scale. The following is used in a dye-house near New York.

Put into a vat 7 by 7 feet, heated by a coil to $160^{\circ} \mathrm{F}$.

$$
\begin{aligned}
& \text { Woad . . . . . . } 500 \text { pounds. } \\
& \text { Indigo . } \quad . \quad . \quad . \quad \cdot 30 \text { pounds. } \\
& \text { Madder } \because . \quad . \quad . \quad .10 \text { pounds. } \\
& \text { Wheat-bran . . . . } 5 \text { pounds. }
\end{aligned}
$$

After standing 12 hours it will require from 15 to 30 quarts of sifted Caustic Lime, added gradually (about 2 quarts at a time) in the course of from 48 to 72 hours.

It will be at once seen that the success of the process depends upon the skill of the operator. 
The Wool is steeped in the bath, then removed and allowed to dry in the air, washed, and dipped again; repeat until the desired shade is obtained.

Note.-By resolution of the Council, the next volume of the Transactions will appear by signatures as often and as rapidly as material can be collected. The Transactions will be sent to Fellows and Members in signatures as issued, or in the completed volume at the close of the year, as each Fellow and Member may elect. Honorary Members will receive the completed volume.

The price of subscription will remain as before.

H. T. VULTE, Recording Secretary, Editor of the Transactions.

Issued Novearber, 1892. 